\title{
El trasfondo de la filosofía kantiana en el compromiso político del pensamiento de Ernst Cassirer (Una presentación a su artículo sobre Judaísmo y los mitos políticos modernos) Kantian Philosophy's Background in The Political Commitment of Ernst Cassirer Thought (A Presentation to Judaism and The Modern Political Myths)
}

\author{
ROBERTO R. ARAMAYO* \\ Instituto de Filosofía del CSIC, Madrid / España
}

\begin{abstract}
RESUMEN: Se traza aquí una panorámica del itinerario intelectual de Cassirer, enfatizando el creciente compromiso político de su pensamiento, al querer combatir la ideología nacionalsocialista desde la historia de las ideas y su filosofía de la cultura simbólica, invocando para ello al espíritu de la Ilustración en general y a Kant muy en particular. Su refutación ideológica del nazismo comienza en 1928 con su homenaje a la República de Weimar y llega hasta 1945 con El mito del Estado, pero aquí se presenta su interpretación del significado peligrosamente moral que tuvo el judaísmo para la ideología totalitaria del nacionalsocialismo.
\end{abstract}

Palabras clave: Cassirer; Kant; Rousseau; Heidegger; Hitler; República de Weimar; Judaísmo.

ABSTRACT: We trace here the layout of Cassirer's intellectual itinerary, highlightning the growing political commitment in his thought as he faces the national socialist ideology from the vantage point of history of ideas and his philosophy of the symbolic forms, invoking in this sense the spirit of Enlightenment in general and Kant in a very particular way as well. Cassirer's ideological rebuttal of Nazism begins in 1928 with his hommage to the Weimar Republic and reaches up to 1945 with The Myth of State. Here

\footnotetext{
*aramayo@ifs.csic.es ORCID iD: http://orcid.org/orcid.org/0000-0002-4771-8306. Este trabajo se adscribe a los Proyectos de Investigación Philosophy of History and Globalisation of Knowledge. Cultural Bridges Between Europe and Latin America: WORLDBRIDGES (F7-PEOPLE-2013-IRSES: PIRSES-GA-2013-612644), PRISMAS filosófico-morales de las crisis: Hacia una nueva pedagogía sociopolítica (FFI2013-42395-P), New Trust-com (S2015-HUM-1466), Cultura de la Legalidad y lucha contra la corrupción (DER2015-71755-REDT) y PAIDESOC. El desván de la razón: Cultivo de las pasiones, identidades éticas y sociedades digitales (FFI2017-88272-P).
} 
however it is presented an interpretation of the dangerously moral meaning that Judaism had for Key words: Cassirer; Kant; Roussea; Heidegger; the totalitarian ideology of National Socialism.

Acaso no haya en el código de los judíos otro pasaje más sublime que éste: "no debes construirte ninguna imagen plástica, ni tan siquiera una alegoría, de aquello que está en el cielo, en la tierra o bajo las aguas" (Exodo 20,4), lo cual explica el entusiasmo del pueblo judío hacia su religión, en comparación con otros pueblos o el orgullo mahometano. Y esto vale igualmente para la representación de la ley moral en nuestra disposición a la moralidad. Allí donde los sentidos no ven nada resta inconfundible la idea de moralidad y se hace aún más imprescindible contener una desbordante imaginación que por temor a su inoperancia pretenda reforzarla con imágenes pueriles. De ahí que los gobiernos permitan que la religión se revista con toda clase de ornamentos, privándonos con ello del empeño y la capacidad de sobrepasar las barreras arbitrarias que se nos imponen, toda vez que la pasividad nos hace mucho más manejables. La exhibición puramente negativa de la moralidad enaltece nuestro ánimo y ahuyenta el peligro de un ilusorio fanatismo, pues el carácter insondable de la libertad anega ese camino.

(Kant, Crítica de la facultad de juzgar, Ak. V 274-275²)

Como es bien sabido, Cassirer se sirvió de su extraordinaria familiaridad con el pensamiento kantiano -cuya obra completa llegó a editar con una esplendida introducción de conjunto- para forjar su filosofía de la cultura, transfiriendo las premisas del sistema transcendental a su Filosofía de las formas simbólicas. Pero quizá no sea tan conocido el uso que hizo del pensamiento kantiano para ir vertebrando su creciente compromiso político ${ }^{2}$, como por otra parte hiciera el propio Kant con la política de su época, según testimonia meridianamente Hacia la paz perpetua ${ }^{3}$. Si Kant se posicionó a favor del republicanismo cosmopolita contra el poder absolutista y aplaudió con entusiasmo la Revolución

${ }^{1}$ Immanuel Kant, Crítica del discernimiento, o de la facultad de juzgar (edición de Roberto R. Aramayo y Salvador Mas), Alianza Editorial, Madrid, 2012, pp. 370-371.

${ }^{2}$ Aun cuando tampoco falten trabajos que apunten en esa dirección como v.g.: Joël Gaubert, La science politique d'Ersnt Cassirer. Pour une refondation symbolique de la raison pratique contre le mythe politique coontemporaain, Kimé, Paris, 1996; Bertrand Bergely, Cassirer. La politique du juste, Michalon, Paris, 1998; Deniz Coskun, Law as Symbolic Form. Ernst Cassirer and The Anthropocentric View of Law, Springer, Dordrecht, 2007.

${ }^{3}$ Cf. Roberto R. Aramayo, "El compromiso político de Kant con la causa republicana conforme a los principios de libertad, igualdad e independencia como derechos de la humanidad", introducción a su versión castellana de I. Kant, Hacia la paz perpetua. Un diseño filosófico, CTK E-Books, Madrid, 2018; cf. asimismo Roberto R. Aramayo, Kant. Entre la moral y la política, Alianza Editorial, Madrid, 2018. 
francesa pese a sus traumáticos e inevitables daños colaterales, a Cassirer le tocó enfrentarse a la ideología totalitaria del nazismo desde la historia de las ideas ${ }^{4}$ y lo hizo evocando constantemente a Kant, tras injertar las líneas maestras del corpus kantiano en su propia reflexión personal.

\section{UNA REFUTACIÓN FILOSÓFICA DEL NACIONALSOCIALISMO (1928-1946)}

Michel Foucault dejó dicho que, cuando las botas de los nazis traspasaron las puertas de la cancillería, la Filosofía de la Ilustración de Cassirer adoptó la figura de un último baluarte, porque -como ha escrito Jean Starobinski- "presentar el cuadro de la Ilustración europea cuando las ideas del nazismo campaban a sus anchas, encontrando en Rousseau el pensamiento que inspiró a Kant, Goethe y la idea republicana, suponía sin perspectiva de alcanzar éxito alguno tanto como poner del revés los mitos que por aquel entonces movilizaban a las masas y que en las universidades encontraban filósofos e historiadores bien dispuestos a propagarlas"s. En la biografía sobre Cassirer que escribió su mujer, Toni Cassirer, se nos relata cómo éste decidió en un momento dado no escribir nunca ni una línea más, al quedar profundamente traumatizado por el ascenso del nazismo al poder, aunque muy pronto cambió de opinión y se aprestó a combatirlo desde la filosofía ${ }^{6}$. Desde luego, a Cassirer le conmocionó sobremanera que personas inteligentes e instruidas, honradas y sinceras, desdeñaran masivamente el mayor privilegio del ser humano, el ser dueños de sí mismos, al dejar de mostrarse críticos con lo que les rodeaba y aceptar esa debacle política como algo natural e inevitable contra lo que no cabía hacer absolutamente nada. En un borrador inédito de El mito del Estado Cassirer consigna el estupor que le causó esa forma de aceptar aquellos hechos:

Durante los primeros días en que Hitler accedió al poder, tuve que oír con frecuencia en labios de gente cultivada, de académicos y filósofos, cómo se repetían una y otra vez las ominosas palabras "ha hablado la Historia". Gente que no era

${ }^{4}$ Cf. Roberto R. Aramayo, "Cassirer, un historiador de las ideas en lucha contra la barbarie del totalitarismo", estudio introductorio a Ernst Cassirer, Rousseau, Kant, Goethe. Filosofia y cultura en la Europa del Siglo de las Luces, Fondo de Cultura Económica, México, 2014, pp. 9-47.

${ }^{5}$ Jean Starobinsky, prefacio a Ernst Cassirer, Le problème Jean-Jacques Rousseau, Hachette, Paris, 1987, p. x.

${ }^{6}$ Toni Cassirer, Mein Leben mit Ernst Cassirer, Felix Meiner, Hamburg, 2003, p. 202. En este orden de cosas, merece consignarse la esplendida biografía intelectual de Massimo Ferrari, Ernst Cassirer. Stationen einer philosophischen Biographie. Von der Marburger Schule zur Kulturphilosophie, Felix Meiner, Hamburg, 2003. 
nada proclive al partido nacionalsocialista cambió repentinamente su parecer. El éxito político era contemplado por ellos como la incontrovertible prueba de la "verdad" y de lo "justo", un juicio irrevocable de la historia, un decreto del fatídico destino. Inclinarse ante los hechos consumados no era sólo una máxima de prudencia política, sino que se consideraba más bien una suerte de imperativo categórico y algo así como el resultado de una profunda sabiduría metafísica ${ }^{7}$.

Cuando Hitler accede al poder absoluto, Cassirer decide redactar una refutación filosófica del ideario nacionalsocialista, aunque retrasará su publicación a instancias de su mujer, para que sus familiares residentes en Alemania no sufrieran represalias, y de hecho sólo se publicará póstumamente bajo el título de El mito del Estado. Esta refutación se mostró eficaz cuando menos con alguien del entorno más cercano a Hitler, como lo era Albert Speer, ese mediocre arquitecto a quien se le encomendó diseñar una megalópolis llamada Germania que sirviera de capital al milenario imperio alemán, pero que sin embargo durante la Segunda Guerra mundial le tocó oficiar como ministro de armamento del Tercer Reich y contribuir indirectamente con su eficacia a la devastación de Berlín, inmortalizada por el cineasta Roberto Rosselini en su impactante film Alemania, año cero. Albert Speer nos cuenta en sus memorias cuánto le impresionó leer a Cassirer durante su cautiverio, mientras cumplía la condena de veinte años que le fue impuesta en el juicio de Núremberg. Según su testimonio, lejos de considerarlo una mera propaganda, la población alemana hizo suyo el slogan de que su líder debía pensar por toda la colectividad y guiar su destino como si fueran menores de edad carentes de toda responsabilidad. "Nuestra disposición a aceptarlo así -escribe Speer- se nos había transmitido desde la infancia y se nos había inoculado la rigidez del orden en la sangre. Frente a eso, la liberalidad de la República de Weimar nos parecía relajada, sospechosa e indeseable" $"$. Algo más adelante confiesa que: "décadas después leí en la prisión de Spandau las palabras de Cassirer sobre quienes por propia iniciativa desdeñan el mayor privilegio del ser humano, el ser dueños de sí mismos. Ahora yo era uno de ellos"9.

\section{LA TRAMA DE NUESTRO UNIVERSO SIMBÓLICO (1939 Y 1944)}

Incapaz de amoldarse a ese ambiente socio-político que le hacía Alemania irrespirable, Cassirer abandonó el rectorado de la Universidad de Hamburgo y se jubiló anticipadamente a los 59 años, partiendo a un exilio que le hizo recalar

${ }^{7}$ Ernst Cassirer, Zu Philosophie und Politik (hrsg. von Michael Krois und Christian Möckel), Felix Meiner, 2008, ECN 9, p. 219 n.

${ }^{8}$ Albert Speer, Memorias. Acantilado, Barcelona, 2003, pp. 63.

${ }^{9}$ Ibid., p. 90. 
unos años en Suecia. Allí decidió rendir homenaje a sus anfitriones académicos y dialogar con la obra del pensador sueco Axel Hägerström. Según señala Cassirer en el prólogo del escrito resultante, esa confrontación le sirvió para aplicar su Filosofía de las formas simbólicas a nuevos ámbitos y dar un giro ético a su pensamiento, al abordar con más detalle los problemas morales y jurídico-filosóficos ${ }^{10}$. Cassirer se pregunta si debemos tirar por la borda todo el itinerario histórico de la ética filosófica, porque se hayan podido entremezclar en su decurso determinadas concepciones metafísicas, o si acaso no resultaría más interesante retener la enjundia de lo conseguido despojándolo de su envoltorio metafísico. Así por ejemplo, los conceptos kantianos del puro deber o de la autonomía ética podrían conservar un significado en términos funcionales que no se ve necesariamente ligado a su revestimiento sustancial. Erradicar antiguas supersticiones es una de las tareas más importantes de la filosofía de la cultura, pero ese desescombro debe servir ante todo para posibilitar una nueva edificación ${ }^{11}$. Esto lo ejemplifica con la evolución del derecho desde los usos y costumbres hacia el veredicto que se orienta hacia el futuro, sin que falte una invocación a la noción kantiana del contrato originario como una idea con indudable realidad práctica y al deber que sólo puede prescribirse uno a sí mismo. La noción misma de voluntad, sin remontarse a sus orígenes de raigambre metafísica, designa únicamente una orientación fundamental de la conciencia hacia lo no dado, lo porvenir que está por realizar y esta función prospectiva, complementaria de la retrospectiva del recuerdo y de la percepción del presente, nos da una capacidad de previsión y anticipación que posibilitan nuestro universo simbólico ${ }^{12}$.

En este orden de cosas, Cassirer define al ser humano en su Antropología filosófica como un animal simbólico, ya que merced a nuestra inmersión en la cultura habitamos en una red simbólica entretejida por los hilos de las formas lingüísticas, las imágenes artísticas, los relatos míticos y los rituales religiosos, todo lo cual nos hace vivir en medio de emociones, esperanzas y temores, ilusiones y desilusiones imaginarias, inspiradas por nuestras fantasías y sueños, más bien que por los crudos hechos o nuestras necesidades y deseos inmediatos $^{13}$. El suicidio de Catón es ante todo un acto simbólico, la última protesta de una mentalidad republicana frente a lo que se le oponía para dar al traste con

${ }^{10} \mathrm{Cf}$. Ernst Cassirer, Filosofia moral, derecho y metafisica. Un diálogo con Axel Hägerström (edición de Roberto R. Aramayo), Herder, Barcelona, 2010, p. 39.

${ }^{11}$ Ibid., p. 125.

${ }^{12}$ Ibid., pp. 148-155.

${ }^{13}$ Ernst Cassirer, Antropología filosófica. Introducción a una filosofía de la cultura (trad. De Eugenio Imaz), Fondo de Cultura Económica, México, 2004, pp. 48-49. 
ella ${ }^{14}$. Y esa fue también la óptica con que Kant enfocó la Revolución francesa, porque lo que le interesaba era captar ese suceso histórico simbólicamente y enjuiciarlo no por su resultado, sino en función de su motivación ética, por la orientación que puso de manifiesto.

\section{EN DEFENSA DE LA REPÚBLICA DE WEIMAR (1928)}

Antes de que se consumara ese giro ético en su pensamiento, Cassirer había dado muestras de su compromiso político en varias ocasiones, entre las que destaca en primer lugar desde un punto de vista cronológico su conferencia sobre La idea de la constitución republicana ${ }^{15}$, impartida para festejar el décimo aniversario de la República de Weimar, a la cual le confiere un valor simbólico similar al que la Revolución francesa recibe por parte de Kant. En esa conferencia manifiesta su íntima convicción de que los problemas del presente no pueden resolverse satisfactoriamente sin afrontar al mismo tiempo las cuestiones fundamentales planteadas por la filosofía, evocando en cierto modo el Artículo secreto de Hacia la paz perpetua, en virtud del cual los estadistas deberían estar más atentos a lo que pudiesen aportar quienes cultivan la filosofía, dada la insoslayable interacción que se da entre teoría y praxis, entre la estructura de las ideas y la configuración de nuestra realidad político-social. A la República de Weimar se le acusaba desde la propaganda nacionalsocialista de ser algo impuesto desde fuera por el ignominioso Tratado de Versalles y que no se compadecía en absoluto con las quintaesencias de lo genuinamente germano.

Para combatir ese prejuicio, Cassirer traza un periplo intelectual que arranca en Leibniz y termina en Kant, dos filósofos alemanes indiscutibles, haciendo ver cómo ciertas ideas leibnizianas habrían sido exportadas a través de Wolff y Blackstone desde Alemania hacia Inglaterra, para llegar luego a Norteamérica y retornar al punto de partida tras pasar por la Francia revolucionaria gracias a las intervenciones de actores políticos como Lafayette o Jefferson. Su conclusión es que la exigencia de los derechos inalienables emergió en la esfera de las ideas con Leibniz y allí permaneció hasta que se consumó su apertura hacia el reino de la historia efectiva, para luego reinsertar ese resultado histórico en lo ideal, al ser proyectados por Kant del reino del ser al del deber ser. Al emprender este viaje hacia el pasado para rastrear los orígenes de la idea de una constitución republicana, Cassirer lo hace con la vista puesta en el porvenir, para imbuir a sus lectores la confianza de que esa carta magna respondía a lo me-

${ }^{14}$ Ibid., p. 292.

${ }^{15}$ Cf. Ernst Cassirer, "La idea de la constitución republicana”, en Isegoria 40 (2009), pp. 155 168, que cuenta con una presentación de quien suscribe (ibid., pp. 149-154). 
jor de su tradición cultural y haciéndola suya podían contribuir a escribir su propio futuro.

\section{UN DUELO FILOSÓFICO EN LA MONTAÑA MÁGICA (1929)}

Sólo un año después de dictar esa conferencia, Cassirer asiste al coloquio de Davos y mantiene un debate con Heidegger que ha devenido legendario ${ }^{16}$, donde se confrontan dos interpretaciones muy divergentes de Kant que, a su vez, reflejan dos maneras antagónicas de entender el papel de la filosofía. Frente al concepto heideggeriano de Geworfenheit, de vernos arrojados-en-el-mundo y condenados a asumir un fatídico destino, Cassirer contrapone lo que denomina en un escrito inédito fechado en 1928 Form-Werdung ${ }^{17}$, algo así como una dinámica de las forma-en-devenir, al ser nuestro futuro simbólico lo que desborda los límites de nuestra existencia finita y nos permite acceder a una infinitud inmanente, dado que la universalidad, validez y aplicabilidad del simbolismo constituye la palabra mágica, el "ábrete sésamo", que nos permite acceder al mundo de la cultura y transcendernos así a nosotros mismos sin poner coto a la libertad. Esa sería justamente la misión de la filosofía, conseguir que seamos tan libres como podamos llegar a serlo gracias a un mundo simbólico, funcional e intersubjetivo, cuya creación autónoma es el mejor sello se la infinitud atribuible al ser humano. La metafísica dogmática de las sustancias debe dejar paso a otra donde tenga cabida una pluralidad de determinaciones y significados funcionales, como Kant habría mostrado particularmente gracias a la facultad de juzgar reflexionante estudiada en su tercera Crítica.

Hay quien ha visto en este torneo dialéctico entre Cassirer y Heidegger una traslación filosófica del debate mantenido entre dos personajes literarios de $L a$ montaña mágica, una novela que Thomas Mann escribió durante los primeros años de la República de Weimar y fue concebida durante una estancia en Davos. Rüdiger Safranski ${ }^{18}$ sugiere que el humanista italiano Settembrini y el jesuita Naphta eran meros portavoces de las controversias en boga durante aquella convulsa época, preguntándose si no habría una correspondencia entre los

${ }^{16}$ Cf. Ernst Cassirer - Martin Heidegger, Débat sur le Kantisme et la Philosophie -Davos, mars 1929- (éd. de Pierre Aubenque), Beauchesne, Paris, 1972; Ernst Cassirer, Cassirer y su NeoIlustración. La Conferencia sobre Weimar y el Debate de Davos con Heidegger (edición de Roberto R. Aramayo), Plaza y Valdés, Madrid, 2009; Kaegi, D. / Rudolph, E., Cassirer-Heidegger. 70 Jahre Davoser Disputation, Felix Meiner, Hamburg, 2002.

${ }^{17}$ Ernst Cassirer, Zur Metaphysik der symbolischen Formen. Nachgelassene Manuskripte und Texte, Felix Meiner, Hamburg, 1995, pp. 4 y 261-171.

${ }^{18}$ Cf. Rüdiger Safranski, Un maestro de Alemania. Heidegger y su tiempo, Tusquets, Barcelona, 2003, p. 224. 
personajes de ficción y los filósofos de carne y hueso. Al parecer Mann podría haberse inspirado en Georg Lukács y no tanto en Heidegger a la hora de perfilar los argumentos de Naphta, pero eso no merma la validez del paralelismo entre el debate filosófico y la controversia literaria. En ambos casos se oponen un abanderado de la ilustración, liberal y anticlerical, contra un devoto de las tradiciones, defensor de los métodos inquisitoriales y contrario a cuanto significó el Renacimiento, por muchos matices que cupiera introducir a esta licencia expositiva que decanta las posiciones enfrentadas de manera emblemáticas. Para el partidario de los valores ilustrados la democracia debe corregir cualquier forma de absolutismo estatal, reivindicando los derechos humanos y la libertad individual, mientras que su contrincante aboga por una pedagogía autoritaria, donde se imponga la obediencia ciega impuesta con mano de hierro y que genere una sumisión total a cuanto decida la voluntad colectiva encarnada en la figura de un líder infalible, prefigurando con todo ello el ambiente socio-político que Leni Riefenstahl filmará en El triunfo de la voluntad.

\section{ROUSSEAU EN KANT (1932 Y 1945)}

En 1932 la situación política de Alemania hace que Cassirer realice una breve estancia en París, para estudiar a Rousseau y discutir en La Sorbona su lectura con los más reputados especialistas franceses en el pensador ginebrino. Como ha señalado certeramente Jean Starobinski, su manera de combatir en pro de ciertas causas consistía en remontar sus fuentes intelectuales y releer los textos de los grandes pensadores para fortalecer con ese riguroso análisis histórico los valores que merecían verse salvaguardados ${ }^{19}$. Según reconoce el propio Cassirer, el legado de Rousseau no es para él simple objeto de una curiosidad erudita o de un examen histórico-filológico, porque las cuestiones que plantea y le hacen oponerse a su siglo no han quedado en modo alguno anticuadas. Puede que sus formulaciones sólo resulten significativas desde un punto de vista historiográfico, pero sus contenidos nos siguen interpelando ${ }^{20}$. Los asertos que Cassirer va desgranando en su lectura de Rousseau no tienen desperdicio, si los consideramos bajo el prisma de una pedagogía socio-política que pretende servir como preventivo al totalitarismo en ciernes.

Cassirer comprueba por añadidura algo que ya sabía y es que Kant, a quien presenta como el moralista por antonomasia del siglo XVIII, el campeón del primado de la razón práctica, fue casi el único que comprendió cabalmente el

\footnotetext{
${ }^{19}$ Cf. op. cit, p. XI.

${ }^{20}$ Cf. Ernst Cassirer, "El problema Jean-Jacques Rousseau”, en Rousseau, Kant Goethe, ed. cit., p. 51.
} 
radicalismo de Rousseau y que demuestra haber hecho suyo cuando afirma que, sin contribuir al triunfo de la justicia, si desapareciera el derecho, dejaría de tener sentido la existencia del ser humano sobre la tierra ${ }^{21}$. Después de todo, fue tras leer a Rousseau cuando Kant decidió dedicarse a defender los derechos de la humanidad ${ }^{22}$. Según leemos en El concepto de filosofía como problema de la filosofia, a juicio de Cassirer, "para Kant toda la filosofía está indisociablemente vinculada con esa cuestión fundamental que conmovió tan honda y apasionadamente al siglo XVIII: la cuestión de los imperecederos, inmutables e inalienables derechos del ser humano"23. Ese mismo significado tenía para Cassirer el papel de la filosofía en general y la filosofía kantiana en particular. Uno de los textos que Cassirer dejó sobre su mesa de trabajo al morir -sólo unos días antes de que se suicidará Hitler- fue un trabajo sobre Kant y Rousseau que, junto a otro sobre Goethe, estaban destinados a servir como introducción a la edición inglesa de su Filosofia de la Ilustración, lo cual muestra que Kant acompañó a Cassirer desde un comienzo y hasta el último momento.

\section{LAS RELACIONES ENTRE FILOSOFÍA Y POLÍTICA (1935 Y 1944)}

En agosto de 1944 le invitaron a impartir una lección sobre las relaciones entre filosofía y política en una universidad estadounidense ${ }^{24}$. Cassirer comienza hablando de la Ilustración y por supuesto no deja de invocar a Kant como ferviente admirador de la Revolución francesa, cuya confianza en el valor ético de las ideas expresadas en la Declaración universal de los derechos humanos de la ciudadanía permanecerá inquebrantable, citando este pasaje de El conflicto de las Facultades: "Esa revolución revela en la naturaleza humana una disposición y una capacidad hacia lo mejor que político alguno hubiera podido argüir a partir del curso de las cosas acontecidas hasta entonces" ${ }^{25}$. Según Cassirer, todos los grandes pensadores del siglo XVIII compartieron que la filosofía cumplía con un importante papel en la vida social y política, al considerar una noción común el conocimiento de que los derechos humanos eran inalienables.

${ }^{21}$ Ibid., p. 89; cf. "Kant y Rousseau", ibid. p. 230 y Ak. VI 332.

${ }^{22}$ Ak. XX 44, en Kant. Antología (edición de Roberto R. Aramayo), Península, Barcelona, 1991, p. 156.

${ }^{23}$ Ernst Cassirer, "Der Begriff der Philosophie als Problem der Philosophie", en Zu Philosophie und Politik, ed. cit., ECN 9, p. 152.

${ }^{24}$ Cf. Ernst Cassirer, "Filosofía y política (1944)" (edición de Roberto R. Aramayo), Arbor 742 (2010), pp. 302-310; cf. Roberto R. Aramayo, "Los climas políticos y las responsabilidades filosóficas", Arbor 742 (2010) pp. 295-301.

${ }^{25}$ Immanuel Kant, El conflicto de las Facultades (edición de Roberto R. Aramayo), Alianza Editorial, Madrid, 2003, p. 164; Ak. VII 88. 
Sin embargo, ese ambiente intelectual fue dando paso -a través del movimiento romántico, la escuela de Savigny o Hegel, a un clima filosófico de un talante muy distinto y, tras la Primera Guerra Mundial, la idea de libertad se ve reemplazada por las de necesidad y fatalidad, cundiendo la desesperación al no poder escapar a nuestro destino, mediante autores tan influyentes como Spengler o Heidegger. Cassirer no afirma que el pesimismo cultural de Spengler o el pensamiento de Heidegger fueran directamente responsable del desarrollo de las ideas políticas en Alemania, porque la ideología del nacionalsocialismo afloró en otros terrenos, pero sí le parece que hay una conexión mediata, toda vez que cuando la filosofía deja de confiar en su propio poder para mostrarnos cómo desarrollar nuestras capacidades en orden a configurar nuestra vida individual y social, se genera un contexto propicio para que las masas puedan verse fácilmente manipuladas por el caudillo político de turno.

\section{EL MITO DEL ESTADO (1946)}

Al referirse a la técnica de los mitos políticos modernos, hacia el final de El mito del Estado, Cassirer sitúa a los ciudadanos víctimas del totalitarismo en ese teatro de marionetas de que nos habla Kant en su segunda Crítica cuando describe a quienes renuncian al principio de autonomía en aras de una moral teológica. En ese caso, nos dice Kant, "el comportamiento del ser humano se transmuta en un simple mecanismo y, como en un teatro de marionetas, todos los muñecos gesticularían a conveniencia, pero sin advertirse vida alguna en ellos" ${ }^{26}$. De igual modo, quienes sucumben a los rituales de los mitos políticos modernos, abducidos por la teología política del nazismo, se ven despojados de su capacidad de juzgar y de su discernimiento crítico, perdiendo con ello su personalidad y abdicando de su responsabilidad individual. He aquí la descripción que hace Cassirer de esas personas convertidas en títeres:

Gentes cultivadas e inteligentes, honradas y rectas, renuncian de repente a la suprema prerrogativa humana, al dejar de ser agentes libres. Ejecutando los mismos ritos, empiezan a sentir, a pensar y a hablar del mismo modo. Sus gestos son animados y violentos, pero ésta es tan sólo una vida artificial y ficticia. Lo que los mueve es una fuerza externa. Actúan como muñecos en un teatro de títeres y ni siquiera saben que los hilos del espectáculo, de toda la vida individual y social, quienes los mueven desde ese momento son los caudillos políticos ${ }^{27}$.

${ }^{26}$ Immanuel Kant, Crítica de la razón práctica (edición de Roberto R. Aramayo), Alianza Editorial, Madrid, 2013, p. 314; Ak. V 147.

${ }^{27}$ Ernst Cassirer, El mito del Estado (traducción de Eduardo Nicol), Fondo de Cultura Económica, México, 1993, p. 338. 
"El político se convierte así en una especie de adivino"28. Aunque no se crea en la magia natural, puede creerse en una especie de magia social, cuando el anhelo de caudillaje alcanza una fuerza abrumadora y se ha desvanecido toda esperanza de cumplir con nuestro deseo por una vía ordinaria. En deseo se personifica bajo una forma concreta, política e individual. Los vínculos sociales anteriores - la ley, la justicia, la constitución-se declaran invalidadas y lo único que queda es el poder místico del caudillo, cuya autoridad es la suprema ley ${ }^{29}$. Estos nuevos taumaturgos son maestros de la propaganda política y saben acuñar nuevas palabras o trastocar el significado de las antiguas para emplearlas como palabras mágicas destinadas a estimular determinadas emociones. El hábil empleo de estas palabras mágicas se combina con la férrea imposición de rigurosos, regulares e inexorables rituales, de suerte que nadie puede andar por la calle ni saludar a su vecino o incluso a un amigo sin ejecutar un rito político cuyo incumplimiento está severamente penalizado. Para Cassirer la mejor vacuna para luchar contra el virus del totalitarismo es lo que propone Kant en ¿Qué es la Ilustración?, aprender a pensar por cuenta propia sin ceder esa responsabilidad a los tutores que nos proponen hacerlo por nosotros, ya que la libertad no es un don, sino la más ardua tarea que nos podemos proponer ${ }^{30}$. Al describir a estos nuevos taumaturgos de los mitos políticos modernos, Cassirer actualiza la denuncia hecha por Kant en El conflicto de las Facultades, texto del que cito un pasaje ligeramente adaptado para la ocasión, porque Cassirer lo suscribe a pie juntillas y piensa como Kant que la filosofía debe desenmascarar a quienes se presentan como salvíficos taumaturgos:

Da la impresión de que la gente anhele encontrar una suerte de adivino o hechicero familiarizado con las cosas sobrenaturales. Si alguien es lo bastante osado como para hacerse pasar por taumaturgo, este conquistará al pueblo y le hará abandonar con desprecio el bando de la filosofía, la cual debe oponerse públicamente a tales taumaturgos para desmentir esa fuerza mágica que el público les atribuye de un modo supersticioso y rebatir las observancias ligadas a ella; como si el encomendarse pasivamente a tan ingeniosos guías dispensara de toda iniciativa propia, al procurar la enorme tranquilidad de alcanzar con ello los fines propuestos ${ }^{31}$.

\section{${ }^{28}$ Ibid., p. 342.}

${ }^{29}$ Cf. Ibid., p. 331.

${ }^{30}$ Cf. Ibid., 332. Cf. Immanuel Kant, ¿Qué es la Ilustración? (edición de Roberto R. Aramayo), Alianza Editorial, 2012.

${ }^{31}$ Immanuel Kant, El conflicto de las Facultades, ed. cit., pp. 80-81, Ak. VII 30-31. La cursiva es mía. 


\section{8. ¿QUÉ SIGNIFICA EL JUDAÍSMO FRENTE A LOS MITOS POLÍTICOS MODERNOS? (1944) ${ }^{32}$}

La panorámica brindada hasta el momento sólo pretende enmarcar dentro del pensamiento de Cassirer, y de su creciente compromiso político desde la filosofía, el texto cuya traducción española se presenta aquí por primera vez y que data de $1944^{33}$. Cassirer pertenecía a una familia burguesa judía, pero también liberal e ilustrada, originaria de Breslau y afincada luego en Berlín, cuya presencia en la cultura alemana resulta comparable a la que tuvo la familia de Wittgenstein en Viena ${ }^{34}$. Sus padres pertenecían a una generación que había dejado de practicar los rituales judíos y en el caso de Cassirer resultaba obvio que Leibniz, Goethe y Kant ${ }^{35}$, junto a la cultura griega y latina, habían tenido en su formación mucha más importancia que la tradición judía, al contrario de lo que sucedía con Cohen, cuyo destino habría sido el de ser rabino pero se convirtió en un notable filósofo gracias al estudio y la interpretación de Kant ${ }^{36}$. Sin embargo, ante los acontecimientos que le tocó vivir, Cassirer asumió un compromiso con el judaísmo ${ }^{37}$, aunque rechazo la idea de su mujer de trasladarse a Palestina, en-

${ }^{32} \mathrm{Cf}$. Irène Kajon, "La philosophie, le judaïsme et le mythe politique moderne chez Ernst Cassirer", en Ernst Cassirer. De Marbourg à New York (sous la direction de Jean Seidengart, Cerf, Paris, 1990, pp. 277-291.

${ }^{33}$ Ernst Cassirer, Ausátze und kleine Schriften (1941-1946) -hrsg. von Birgit Recki, en Ernst Cassirer Werke (Hamburger Ausgabe), EWC 24, Felix Meiner, Hamburg, 2007, pp. 197-208. La paginación incluida entre corchetes remite a las páginas del volumen 24 de la EWC o edición de Hamburgo de las obras completas de Cassirer. Fue publicado originalmente en Contemporary Jewish Record 7 (1944) pp. 115-126. A continuación se presenta la traducción española, asimismo inédita, de un manuscrito homónimo adjetivado de Paralipomena y que está recogido en Ernst Cassirer, Nachgelassene Manskripte und Texte, vol. 9: Zu Philosophie und Politik mit Beilagen (hrsg. von Michael Krois und Christian Möckel), Felix Meiner Verlag, Hamburg, 2008 (ECN 9), pp. 267-273. Este último manuscrito parece ser un borrador del artículo anterior y fue publicado previamente por Donald Phillip Verene en su recopilación de opúsculos aparecida bajo el título de Symbol, Myth and Cultur. Essays and Lectures of Ernst Cassirer (1935-1945), Yale University Press, New Haven and London, 1979, pp. 233-241.

${ }^{34}$ Carole Maigné, Ernst Cassirer, Belin, Paris, 2013, p. 9.

${ }^{35}$ Cuando Bruno Bauch reprochó a Cohen y Cassirer, en el seno de los Kant-Studien, que ambos practicaban algo así como un "formalismo judío" y eran meros invitados del hogar alemán, Cassirer le contestó citando a Goethe que "nuestra patria reside allí donde nos educamos"; cf. Zum Begriff der Nation (1916), ECN 9, p. 52.

${ }^{36}$ Cf. Toni Cassirer, op. cit., pp. 94-95.

${ }^{37}$ El último texto que Cassirer leyó en Alemania antes de partir al exilio versaba sobre su relectura de la Religión de la razón extraída de las fuentes del judaísmo, publicado por Hermann Cohen en 1919. Esta lectura tuvo lugar en la sinagoga de la Prinzenregentenstrasse de Berlín el 22 de enero de 1933 y el texto se titula "La filosofía de la religión de Hermann Cohen y su relación con el judaísmo” (ECW 18, p. 260). 
tre otras cosas porque no se veía capaz de aprender hebreo a sus años para proseguir allí su trabajo universitario ${ }^{38}$, aunque se vio obligado a aprender sueco e inglés, idioma en que está redactado el texto aquí presentado.

En el borrador del Judaísmo y los mitos políticos modernos, Cassirer anota que preguntarse por la "verdad" del mito político carece tanto de sentido y es tan ridículo como preguntarse por la verdad de un fusil o de un avión de combate, pues ambos son armas y las armas sólo prueban su verdad mediante su eficacia ${ }^{39}$. El mito siempre tuvo un carácter dramático y concibe el mundo como una lucha titánica entre fuerzas antagónicas. De ahí que el proceso de deificación del líder indiscutible quede incompleto hasta contrastarlo con la demonización del enemigo por antonomasia. Había sin duda un clima social de antisemitismo, pero a los nazis no les preocupaba, como dijo su propaganda en un principio, la influencia de los judíos en la sociedad alemana, que podía explicar el odio personal, la envidia económica o ciertos prejuicios, cuanto un atentado contra la supremacía ideológica pretendida por el nazismo. Negarla era un pecado mortal, un crimen contra el todopoderoso e infalible Estado totalitario. Y los judíos eran culpables del crimen de alta traición y de lesa majestad por su tradición, su cultura y su vida religiosa. El odio que la ideología del nazismo expandió en los años treinta contra los judíos respondía en gran parte al hecho de que este pueblo había dado el paso desde una religión mítica a una religión ética ${ }^{40}$.

Para llevar a cabo este análisis, Cassirer recurre una vez más a Kant y comienza por reparar en un pasaje contra la idolatría que se ha puesto como lema del presente estudio introductorio. En ese fragmento de su tercera Crítica Kant alaba este paso dado por la religión judía contra el culto a las imágenes y a cualquier representación sensible, estableciendo un paralelismo con la pureza que debe acompañar a nuestra representación de la ley moral. De ahí que Cassirer pueda caracterizarlo como un tránsito de una religión mítica hacia otra de índole moral. Despojar al mito de la idolatría es afianzar su decadencia. Bien al contrario, el nacionalsocialismo ensalzaba la hermandad de sangre para divinizar a la raza, mientras que el judaísmo había transitado hacia un universalismo a partir del cual surge un ideal de paz perpetua. "Hubieron de pasar más de dos mil años - escribe Casssirer- para que esta idea fuera defendida e interpretada por un gran pensador filosófico. Al final del Siglo de la ilustración Kant escribió su ensayo Hacia la paz perpetua" (24, 205-206).

${ }^{38}$ Cf. Toni Cassirer, op. cit., p, 214-215.

${ }^{39} \mathrm{Cf}$. Symbol, Myth and Cultur. Essays and Lectures of Ernst Cassirer (1935-1945), Yale University Press, New Haven and London, 1979, p. 237.

${ }^{40}$ Ibid., p. 240. 
Esto parece un ideal imposible, mera utopía, pero los profetas judíos no temieron proclamar esa utopía, porque vivir en la idea -dice Goethe- significa intentar lo imposible como si fuera posible. Contra este ferviente anhelo de paz perpetua nuestros mitos políticos modernos tienden a perpetuar e intensificar la guerra, prometiendo al pueblo alemán la conquista del mundo entero y practicando el exterminio de su peor enemigo ideológico, el pueblo judío. "En su nueva mitología política los líderes de Alemania eligen lo judío como chivo expiatorio sobre el que cargar todos los pecados y males imaginables. Lo que temían los inventores del mito de la raza superior alemana no es la resistencia física, sino la resistencia moral de los judíos. Y quisieron asegurarse de quebrar su resistencia" $(24,207)$.

Tras comprometerse políticamente con la República de Weimar y defender una interpretación de Kant en las antípodas de la heideggeriana o servirse de los planteamientos kantianos en clave simbólico-funcionalista para desarrollar su filosofía de la cultura, invocando al mismo tiempo el espíritu de la Ilustración para recordar el imperio de una legislación autónoma con Rousseau, Cassirer se compromete con el significado que Kant le había dado al judaísmo para proseguir su refutación de la perversa ideología nacionalsocialista. El admirador de Kant y Goethe, identificándose ahora como un miembro de la comunidad judía, termina su texto diciendo lo siguiente: "Nos tocó representar esos ideales que han sido enarbolados por el judaísmo y han encontrado su camino en la cultura humana universal, en la vida de las naciones civilizadas. Esos ideales no pueden ser destruidos. Si el judaísmo ha contribuido a quebrar el poder de los mitos políticos modernos, ha cumplido con su deber y su misión histórica" $(24,208)$.

\section{BIBLIOGRAFÍA}

Aramayo, R.R.: "Los climas políticos y las responsabilidades filosóficas", Arbor 742 (2010) pp. 295-301.

Aramayo, R.R.: "Cassirer, un historiador de las ideas en lucha contra la barbarie del totalitarismo", estudio introductorio a Ernst Cassirer, Rousseau, Kant, Goethe. Filosofia y cultura en la Europa del Siglo de las Luces, Fondo de Cultura Económica, México, 2014, pp. 9-47.

Aramayo, R.R.: "El compromiso político de Kant con la causa republicana conforme a los principios de libertad, igualdad e independencia como derechos de la humanidad", introducción a su versión castellana de I. Kant, Hacia la paz perpetua. Un diseño filosófico, CTK E-Books, Madrid, 2018.

Aramayo, R. R.: Kant. Entre la moral y la política, Alianza Editorial, Madrid, 2018. Bertrand Bergely, Cassirer. La politique du juste, Michalon, Paris, 1998. 
Cassirer, E.: El mito del Estado (traducción de Eduardo Nicol), Fondo de Cultura Económica, México, 1993.

Cassirer, E.: Zur Metaphysik der symbolischen Formen. Nachgelassene Manuskripte und Texte, Felix Meiner, Hamburg, 1995.

Cassirer, E.: Antropología filosófica. Introducción a una filosofía de la cultura (trad. De Eugenio Imaz), Fondo de Cultura Económica, México, 2004, pp. 48-49.

Cassirer, E.: Ausátze und kleine Schriften (1941-1946) -hrsg. von Birgit Recki, en Ernst Cassirer Werke (Hamburger Ausgabe), EWC 24, Felix Meiner, Hamburg, 2007.

Cassirer, E.: Nachgelassene Manskripte und Texte, vol. 9: Zu Philosophie und Politik mit Beilagen (hrsg. von Michael Krois und Christian Möckel), Felix Meiner Verlag, Hamburg, 2008 (ECN 9).

Cassirer, E.: "La idea de la constitución republicana”, en Isegoria 40 (2009), pp. 155-168.

Cassirer, E.: Cassirer y su Neo-Ilustración. La Conferencia sobre Weimar y el Debate de Davos con Heidegger (edición de Roberto R. Aramayo), Plaza y Valdés, Madrid, 2009.

Cassirer, E.: "Filosofía y política (1944)" (edición de Roberto R. Aramayo), Arbor 742 (2010), pp. 302-310.

Cassirer, E.: Filosofía moral, derecho y metafísica. Un diálogo con Axel Hägerström (edición de Roberto R. Aramayo), Herder, Barcelona, 2010, p. 39.

Cassirer, E.: Rousseau, Kant, Goethe. Filosofía y cultura en la Europa del Siglo de las Luces, Fondo de Cultura Económica, México, 2014.

Cassirer, E. - Heidegger, M. Débat sur le Kantisme et la Philosophie-Davos, mars 1929 (éd. de Pierre Aubenque), Beauchesne, Paris, 1972.

Cassirer, T.: Mein Leben mit Ernst Cassirer, Felix Meiner, Hamburg, 2003.

Coskun, D.: Law as Symbolic Form. Ernst Cassirer and the Anthropocentric view of Law, Springer, Dordrecht, 2007.

Ferrari, M.: Ernst Cassirer. Stationen einer philosophischen Biographie. Von der Marburger Schule zur Kulturphilosophie, Felix Meiner, Hamburg, 2003.

Gaubert, J.: La science politique d'Ersnt Cassirer. Pour une refondation symbolique de la raison pratique contre le mythe politique coontemporaain, Kimé, Paris, 1996.

Kajon, I.: "La philosophie, le judaïsme et le mythe politique moderne chez Ernst Cassirer", en Ernst Cassirer. De Marbourg à New York (sous la direction de Jean Seidengart, Cerf, Paris, 1990, pp. 277-291.

Kaegi, D. / Rudolph, E.: Cassirer-Heidegger. 70 Jahre Davoser Disputation, Felix Meiner, Hamburg, 2002.

Kant, I.: Kant. Antología (edición de Roberto R. Aramayo), Península, Barcelona, 1991.

Kant, I: El conflicto de las Facultades (edición de Roberto R. Aramayo), Alianza Editorial, Madrid, 2003. 
Kant, I.: ¿Qué es la Ilustración? (edición de Roberto R. Aramayo), Alianza Editorial, 2012.

Kant, I.: Crítica del discernimiento, o de la facultad de juzgar (edición de Roberto R. Aramayo y Salvador Mas), Alianza Editorial, Madrid, 2012.

Kant, I.: Crítica de la razón práctica (edición de Roberto R. Aramayo), Alianza Editorial, Madrid, 2013.

Maigné, C.: Ernst Cassirer, Belin, Paris, 2013.

Safranski, R.: Un maestro de Alemania. Heidegger y su tiempo, Tusquets, Barcelona, 2003.

Speer, A.: Memorias. Acantilado, Barcelona, 2003, pp. 63.

Starobinsky, J.: prefacio a Ernst Cassirer, Le problème Jean-Jacques Rousseau, Hachette, Paris, 1987.

Verene, D. P.: Symbol, Myth and Cultur. Essays and Lectures of Ernst Cassirer (19351945), Yale University Press, New Haven and London, 1979. 